\title{
The Influence of Transformational Leadership in Moderating Job Satisfaction and Intrinsic Motivation on Teachers' Task Performance
}

\author{
Slamet Fauzan ${ }^{1 *}$, Siti Mariyah ${ }^{2}$, Yongky Teguh Setiaji ${ }^{3}$ \\ ${ }^{1,2,3}$ State University of Malang \\ "Corresponding author. Email: slamet.fauzan.fe@um.ac.id
}

\begin{abstract}
The development of education has several important points to be developed. One of them is through teachers' performance. Teachers' role becomes important in generating high quality and competitive graduates. Quantitative method with multiple regression analysis technique was used to observe the influence of work satisfaction and intrinsic motivation towards teachers' performance which was moderated by transformational leadership. The sample consisted of 149 Vocational High School teachers in Pemalang Regency. The research finding showed that there was significant effect of work satisfaction and intrinsic motivation towards teacher's performance which was moderated by transformational leadership.
\end{abstract}

Keywords: Work Satisfaction, Intrinsic Motivation, Transformational Leadership, Teacher's Performance

\section{INTRODUCTION}

Nowadays, the development of education needs human resources with high quality and competitiveness in revolution 4.0 era (Prasetyo \& Trisyanti, 2019). The characteristic of education system in this era has focuses on; learning as needed, teachers as mentor, and formative test (Komarudin, 2020). Teachers as the first relay holder to increase the quality of human resources. It similar with the previous statement that teacher's role is important to get the effective and efficient learning system (Komarudin, 2020; Topchyan \& Woehler, 2020).

Teachers' role to get the best graduates are supported well by the government. The policy which given by the government was through teacher's training and accompaniment, especially for Vocational High School (Harususilo, 2018). It is because the unemployment rate by Vocational High School graduates is high. Therefore, teachers' performance need to be increased to solve the problem. Based on BPS data, the total unemployment of Vocational High School graduates in 2020 reached $8,49 \%$ (BPS, 2020). In the other hand, the problem in Indonesia related to teachers' performance is considered low (Murdaningsing, 2019). Several problems which is faced by the education world in Indonesia brings Vocational High School revitalization program as the program which is run by the government to get high- quality graduates. In 2020-2024, this program is not partial revitalization, but total revitalisation (Uly, 2019). This program indicates that there is problem in Vocational High School by focusing on 4 main points, those are: curriculum, the educators and education personnel, collaboration, and the graduates. Because of that, the program given by the government in education sector has crucial role to get high quality human resources.

Human resources can increase work condition and performance in current disruption era as the form of education accountability (Green \& Muñoz, 2016). The development of teachers' performance need to be noticed in creating the expected quality of human resources. In increasing the performance, the booster factor is needed from the inside and outside (Tentama, 2015). The previous research which studied about teachers' performance was influenced by several factors such as work satisfaction (Ellis, et. al, 2017; Kafumbu, 2019) and work motivation (Fatati, et. al, 2017; Gutteres \& Suparta, 2018). The existence of the inner booster does not influence teachers' performance entirely, however the existence of the leaders also influence the process of the increasing performance (Tesfaw, 2014).

The previous research got inconsistent result, the research with work satisfaction result has a positive 
significant effect towards the performance (Werang, 2014; Dou, et. al, 2017). However, the research conducted by Fu \& Deshpande (2014) showed negative impact towards the performance. Intrinsic motivation has positive significant effect towards the performance (Fatati, et. al, 2017; Farhah, et. al, 2020; Ahmadiansah, 2016), while the result of research conducted by Noermijati (2015) showed a negative impact. The research conducted by Nasra (2019) showed that transformational leadership has a positive significant effect towards the performance. In the other hand, research conducted by Shahab \& Nisa (2014) showed that transformational leadership has negative significant effect towards the performance. Based on the previous result of the studies, the gap and the different result are found. Therefore, it is necessary to do another research. The gap of the research is by making transformational leadership as moderation variable. The difference with the other researches is the observation period and making the teachers as target of population.

\section{LITERATURE REVIEW}

\subsection{Grand Theory}

Maslow's theory of need which was developed by Abraham (1994), divides the basic human needs into five parts. The needs are related one another. If one need is achieved, people will be motivated to achieve the other needs. Those five basic needs are:

a. Physiological needs, as the very basic needs of the human to have a proper life

b. Safety needs, as the need required by human being to get a safety so they are able to do activities comfortably.

c. Social needs, as the need to socialize among humans

d. Appreciation needs, as the appreciation from other people as one of the enthusiasms and motivation to achieve the next target.

e. Self-Actualization, as the highest need of all human needs.

Work satisfaction, intrinsic motivation, transformational leadership, and performance has tight relationship with Maslow's theory of need (Tentama, 2015; Fatati, et. al, 2017). Mangkunegara (2006) explained that there are some factors from the inner side of the human which has effect towards the performance. Because of that, Maslow's theory of need considered by the researchers as a proper theory to do further research about the effect of work satisfaction and intrinsic motivation towards teachers' performance moderated by transformational leadership.

\subsection{Work Satisfaction}

Robbins in Tentama (2015) defined that work motivation is the happiness degree of the human towards occupation. Regarding to humans' self-happiness, Kafumbu (2019) confirmed that work satisfaction appeared as a result of the responsibility conducted towards the work. The emerge of work satisfaction will bring positive effect towards human work pattern (Green \& Muñoz, 2016; Ellis, et. al, 2017). Robbert Hoppock in Green \& Muñoz (2016) stated that there are some factors which affect teachers' work satisfaction, those are (a) individual reaction towards unpleasant situation; (b) behaviour and interaction; (c) social and economic status which is identified by someone; (d) the work related to interest ability; (e) safety; and (f) loyalty towards organization. Based on those factors, it can be concluded that work satisfaction has relationship towards the fulfilment of a human need.

The previous research stated that work satisfaction had positive significant effect towards teachers' performance (Green \& Muñoz, 2016; Tentama, 2015; Sofyan, et. al, 2020; Widayati, et. al, 2020; Koedel, et. al, 2017; Nagar, 2012; Ellis, et. al, 2017; Kafumbu, 2019; Fatati, 2017; Werang, 2014; Bayu, 2017; Ahmadiansah, 2016; Kakiay, 2017). The result is contrast with research conducted by Rustamaji, et. al (2017) which stated if the work satisfaction does not have significant effect towards the performance. The research conducted by using 834 samples from 1032 teachers in East Jakarta. Work satisfaction did not affect the performance due to work satisfaction is a part of mediation which causes the existence another variable which could not be explained in the research affecting teachers' performance (Rustamaji, et. al, 2017). It becomes interesting because in this research, work satisfaction towards performance which was moderated by transformational leadership will be found. Work satisfaction has a tight relation towards self- actualization, the higher someone's satisfaction, the better the performance resulted. Based on the previous research and linked to the theory used, the researchers propose some hypothesis.

\subsection{Intrinsic Motivation}

Intrinsic motivation is the inner booster of human being which has a high contribution towards the success of the work (Siagian, 2007). Motivation has a tight relation with something which can provoke enthusiasm in doing the work (Alhusaini, et. al, 2020). This is in line with the previous research conducted by Ahmadiansah (2016) which stated that enthusiasm could provoke stimulus affecting someone's action and behaviour. As'ad (2008) defined work motivation as something encouraging work enthusiasm. Talking about motivation, it can be said that motivation is human's basic needs. Each activity done by human needs a motivation. 
Therefore, motivation is one of human's basic needs (Fatati, 2017).

Motivation has significant effect towards performance (Fatati, 2017; Ahmadiansah, 2016; Alhusaini, 2020; Gutteres \& Supartha, 2016). The significant effect of motivation towards performance proofs that motivation, especially inner motivation is very important in supporting work. It has tight relationship with work satisfaction, motivation will generate self-satisfaction. Therefore, the performance resulted will also better. In other words, the higher motivation in human's life, the better performance resulted.

\subsection{Transformational Leadership}

Leadership is one element that cannot be separated from the performance, because someone will work under the command of the leader. Keith in Guterres \& Supartha (2016) stated leadership as a part of management. It is the ability to affect others. Transformational leadership has tight relationship with time because this leadership style needs quite long time to increase the work performance (Rustamaji, et. al, 2017). Moreover, it is stated that transformational leadership can advance the teaching process generally if three factors are fulfilled. Those factors are modelling behaviour, inspirational group purpose, and contingent appreciation.

Transformational leadership has significant influence towards work (Tesfaw, 2014; Werang, 2014; Dou, et. al, 2017; Suyanto, et. al, 2019). Transformational leadership increases followers motivation, work satisfaction, work performance, and organization commitment (Bono \& Judge, 2003]. It is different from the research conducted by Dhaniel et, al. (2020) which stated that transformational leadership does not have significant effect towards teachers' performance. It is revealed because quite long time in a leadership is required to increase the performance. Related to Maslow needs theory, transformational leadership has tight relationship with social needs because social relationship is found in an organization.

\subsection{Teacher's Performance}

Borman (1993) stated that performance is divided into two parts, those are assignment performance and contextual performance. Assignment performance has a tight relationship with the core of organization, for example teachers' teaching and learning activity in the classroom (Rustamaji, et. al, 2017), whereas contextual performance has tight relationship with the environment. A strong commitment from the organization will strengthen someone's performance (Dou, et. al, 2017). It can be seen from the needs of perspective, performance is very affected by various factors from oneself.
Therefore, motivation, enthusiasm and support from organization affect the performance.

Other things is revealed in the research conducted by Widayati, et. al (2020), that teachers' performance also affect various actions which will be done. This is in line with the previous research which stated that the performance will affect the process of the action done by someone in doing the assignment (Alhusaini, et. al, 2020; Hutagulung, et. al, (2020). Maslow's theory of needs which covers all kinds of needs is considered correct by the researchers as literature review in this research. Based on the review and the result of the previous research, the researcher proposes the hypotheses as follow:

H1: Work performance has positive effect towards teachers' performance.

$\mathrm{H} 2$ : Intrinsic motivation has positive effect towards teachers' performance.

H3: Transformational leadership moderated work satisfaction and intrinsic motivation towards teachers' performance.

\section{RESEARCH METHOD}

This research applied quantitative method to test the relationship of the variable used by the researchers. Population chosen by the researcher was all teachers in Public Vocational High School of Pemalang regency. The reason why researchers chose teachers in Public Vocational High School of Pemalang regency based on BPS data in Februari 2020 is that the highest unemployment rate was from Vocational High School graduates, it reaches $8,49 \%$. That number showed that teachers' performance are low which cause unprofessional graduates, Vocational High School graduates could not compete with others. The population in this research presented below:

Table 1 Research population list

\begin{tabular}{llc}
\hline No & School Name & Number of teacher \\
\hline 1. & SMK N 1 Pemalang & 87 \\
2. & SMK N 1 Ampelgading & 77 \\
3. & SMK N 1 Petarukan & 54 \\
4. & SMK N 1 Randudongkal & 19 \\
\cline { 2 - 2 } & & 237
\end{tabular}

The sample of this research is 149 of teachers in Public Vocational High School of Pemalang regency. To determine the sample, the researcher applied Slovin formula, as follow:

$$
n=\frac{N}{1+N e^{2}}
$$


Where;

$\mathrm{n}=$ the number of samples

$\mathrm{N}=$ the number of populations

$\mathrm{e}=$ the border of tolerance (error tolerance $)$

Before applying this formula, firstly, researchers should determine error tolerance. The smaller error tolerance, the more accurate the sample would be. Therefore, the researcher determined the error tolerance $5 \%$.

$$
\mathrm{n}=\frac{237}{1+237 \cdot(0,05)}=\frac{237}{1,5925}=148,82
$$

Based on the result, the number of samples is 148,82 . To increase the accuracy of the research result, so the researchers conducted a rounding to 149 .

Table 2 The List of Every Population Sample

\begin{tabular}{llcc}
\hline No & \multicolumn{1}{c}{ School Name } & $\begin{array}{c}\text { Population } \\
\text { Number }\end{array}$ & $\begin{array}{c}\text { Sample } \\
\text { Number }\end{array}$ \\
\hline 1 & SMK N 1 Pemalang & 87 & 55 \\
2 & SMK N 1 Ampelgading & 77 & 49 \\
3 & SMK N 1 Petarukan & 54 & 34 \\
4 & SMK N 1 Randudongkal & 19 & 11 \\
\cline { 3 - 4 } & & & 149
\end{tabular}

The researcher collected the data by giving questionnaires as the instrument in questions form. Those questionnaires were used to reveal the variable of work satisfaction and intrinsic motivation towards teachers' performance which is moderated by transformational leadership. To analyse the result from the questionnaire, the researcher applied multiplied regression analysis to know the effect among variables.

\section{RESULTS AND DISCUSSION}

\subsection{Description Analysis}

Table 3 shows descriptive statistic dependent, independent, and moderation of the variable of this research. The average score of teachers' performances was considered high amount of $82,25 \%$. This indicates that the performance of Vocational High School teachers in Pemalang has been in good criteria with the assessment conducted by the colleagues who basically were not in class entirely to see the teachers' performance directly.

The average score of work satisfaction showed $78,81 \%$. This score showed Vocational High School teachers in Pemalang have good satisfaction in their works. With standard deviation lower than the mean which mean the spread of the score is prevalent. The average of intrinsic motivation in this research is $87,37 \%$ with standard deviation amount of $5,44 \%$. The percentage showed teachers' motivation have good criteria. Moderation variable in this research is transformational leadership that showed the average is $81,54 \%$ which mean that the leadership has been good enough.

Table 3 Descriptive Standard

\begin{tabular}{|c|c|c|c|c|c|}
\hline & Variables & Minimum & Maximum & Mean & $\begin{array}{c}\text { Std. } \\
\text { Deviation }\end{array}$ \\
\hline $\mathrm{Y}$ & $\begin{array}{l}\text { Assignment } \\
\text { Performance }\end{array}$ & 58.33 & 100.00 & 82.248 & 7.516 \\
\hline$X_{1}$ & $\begin{array}{l}\text { Work } \\
\text { satisfaction }\end{array}$ & 50.00 & 100.00 & 78.807 & 75.374 \\
\hline$X_{2}$ & $\begin{array}{l}\text { Intrinsic } \\
\text { Motivation }\end{array}$ & 64.00 & 98.67 & 87.373 & 5.4371 \\
\hline $\mathrm{Z}$ & $\begin{array}{l}\text { Transformational } \\
\text { Leadership }\end{array}$ & 62.00 & 96.00 & 81.543 & 65.435 \\
\hline
\end{tabular}

Source: Primary Data processed 2020

\subsection{Regression Result}

Based on regression accounting in table 4.2, the formula for regression equation is as follow;

$$
\begin{aligned}
Y= & 43,473+0,294 X_{1}+0,212 X_{2}+0,487 Z+4,485\left[X_{1}\right. \\
& -Z]-3,282\left[X_{2}-Z\right]
\end{aligned}
$$

The result of regression test showed p score which is less than 0,05 which mean work satisfaction has significant effect. The score of R Square in model 1 is 0,0506 so $X_{1}$ and $X_{2}$ in this research can explain $50,6 \%$ variasion of teachers' performance. It showed that work satisfaction has positive significant effect towards teachers' performance. From that table, we can conclude that each work satisfaction and intrinsic motivation has 0 (zero) score. Therefore, teachers' performance is $0,43 \%$. If IC score increases $1 \%$, then teachers' performance will increase $29,4 \%$ with the assumption the score of the other independent variables is 0 . However, if intrinsic motivation increases $1 \%$, then teachers' performance increases 21,2 \%. Meanwhile, for $\mathrm{p}$ score of intrinsic motivation showed higher result than 0,05 which mean that it does not have significant effect. Positive coefficient showed that independent and dependent variable are in the same way, meanwhile negative

\begin{tabular}{|c|c|c|c|c|c|c|}
\hline & \multirow[t]{2}{*}{ Model } & $\begin{array}{l}\text { Unstandard } \\
\text { ized } \\
\text { Coefficient } \\
\text { s }\end{array}$ & & $\begin{array}{c}\text { Standardi } \\
\text { zed } \\
\text { Coefficie } \\
\text { nts }\end{array}$ & \multirow[t]{2}{*}{$\mathrm{t}$} & \multirow[t]{2}{*}{$\begin{array}{c}\text { Sig } \\
.\end{array}$} \\
\hline & & B & $\begin{array}{c}\text { Std. } \\
\text { Erro } \\
\text { r }\end{array}$ & Beta & & \\
\hline & (Consta & & 212 & & $\begin{array}{c}- \\
204\end{array}$ & .04 \\
\hline 1 & nt) & -43473 & 97 & & $\begin{array}{c}1 \\
775\end{array}$ & $\begin{array}{c}3 \\
.00\end{array}$ \\
\hline & $\mathrm{X}_{1}$ & .294 & .038 & .486 & $\begin{array}{c}8 \\
277\end{array}$ & $\begin{array}{c}0 \\
.00\end{array}$ \\
\hline & $\mathrm{X}_{2}$ & .212 & .076 & .184 & 2 & 6 \\
\hline
\end{tabular}
coefficient showed the opposite way.

Table 4 the result of multiple regression analysis 


\begin{tabular}{lccccc} 
& & & & 525 & .00 \\
$\mathrm{Z}$ & .487 & .093 & .328 & 2 & 0 \\
$\mathrm{AbsX} 1$ & & 107 & & 418 & .00 \\
$\mathrm{Z}$ & 4485 & 2 & .278 & 3 & 0 \\
& & & & - & \\
AbsX2 & & 126 & & 259 & .01 \\
$\mathrm{Z}$ & -3282 & 4 & -.173 & 6 & 0 \\
\hline Source: Primary Data processed 2020 &
\end{tabular}

\subsection{Hypothesis Test}

Table 5 shows the counting result of $\mathrm{F}$ is 29,304 . Thus, all independent variables affect dependent variable. In other words, with significance 0,003 all independent variables affect dependent variables.

Table 5. The Test of Simultaneous Hypothesis

\begin{tabular}{lllrrrr}
\hline \multicolumn{1}{c}{ ANOVA $^{\mathbf{b}}$} \\
\hline Model & $\begin{array}{c}\text { Sum of } \\
\text { Squares }\end{array}$ & df & $\begin{array}{c}\text { Mean } \\
\text { Square }\end{array}$ & F & Sig \\
\hline 1 & Regression & 10.998 .852 & 5 & 2.199 .770 & 29.304 & .000 \\
& Residual & 10.734 .464 & 143 & 75.066 & & \\
Total & 21.733 .315 & 148 & & & \\
\hline
\end{tabular}

a. Predictors: (Constant), AbsX2_Z, Z, X1, AbsX1_Z, X2

b. Dependent Variable: Y

Table 6 Coefficient of Simultaneous Determinant $\left(\mathrm{R}^{2}\right)$

\begin{tabular}{rcrcc}
\multicolumn{5}{c}{ Model Summary } \\
\hline Model & $\mathrm{R}$ & $\begin{array}{c}\mathrm{R} \\
\text { Square }\end{array}$ & $\begin{array}{c}\text { Adjusted R } \\
\text { Square }\end{array}$ & $\begin{array}{c}\text { Std. Error of } \\
\text { the Estimate }\end{array}$ \\
\hline 1 & $.711^{\mathrm{a}}$ & .506 & .489 & 866.407 \\
\hline a. Predictors: (Constant), AbsX2_Z, Z, X1, AbsX1_Z, \\
X2
\end{tabular}

Model 1 showed the score of R's2 is 0,506 which mean that the change variable of $\mathrm{Y}$ is affected by the change of $X 1, X 2$ and $Z$ which is $50,6 \%$. So, the effect of the work satisfaction, intrinsic motivation towards assignment performance with transformational leadership as moderating variable is $50,6 \%$, whereas the rest $49,4 \%$ is affected by another factor which is not included in this research.

\section{DISCUSSION}

This study found the effect of positive significant among work satisfaction towards teachers' performance is quite high, which is $29,4 \%$. It can be said that the higher work satisfaction, the better the performance given. The result of this research supports the previous research conducted by Green \& Muñoz (2016), Dou, et. al (2017), Widayati, et. al (2020), and Koedel, at. al, (2017). However, it does not support the research conducted by Shahab \& Nisa (2014) and Rustamaji, et. al (2017), which showed that Vocational High School teachers in Pemalang oriented in organisational value, not only hoping a return. Thus, the achievement of the purpose in teaching learning process become the focus of the teachers' performance.

Teachers' work satisfaction need being noticed to increase their performance, as told in Kafumbu research (2019) that the low of work satisfaction affect given performance. Thus, the policy maker set the policy to increase a work satisfaction. Work satisfaction means emotional relation towards the organisation, it includes the involvement in its scope.

This research also shows positive effect of intrinsic motivation towards teachers' performance. It indicates when inner motivation is a high, so the performance is also good. Based on the result of statistic test, it also stated that intrinsic motivation of Vocational High ig. School teachers in Pemalang is good enough. The increase of the performance is started by the effort to grow the encouragement or motivation (Krivonos, 2006). This finding is in line with the result of studies conducted by Fatati, et. al (2017) and Ahmadiansah (2016).

Transformasional leadership also gives an impact towards work satisfaction, intrinsic motivation towards teachers' performance. The role of the leader become crucial in determinig teachers' performance. The result of this research shows that moderation variable can strengthen the relationship between independent and dependent variable. Basically, the leader provides a movement for organisation to achieve its purpose (Dou, et. al, 2017). This research is in line with Maslow's theory of need which explains about self -actualization towards the needs to increase the performance.

\section{CONCLUSIONS}

This research tested the effect of work satisfaction and intrinsic motivation towards assignment performance with transformational leadership as moderating variable to Vocational High School teachers in Pemalang. Based on hypothesis test, there are two things that can be concluded. First, work satisfaction and intrinsic motivation affect positively towards teachers' performance and transformational leadership moderated the variable of the research. Moreover, this finding is also in line with the assumption of Maslow's theory of need. The result of this research can become the consideration to set the policy for various parties. For Vocational High School, it can be as the input to manage the teachers in increasing their performance. For Education, Youth and Sports Service, it can be as the consideration in setting the policies. The suggestion for the next researcher is to search other factor affecting teachers' performance directly, because in this research, it could not be maximum because of those three factors. 


\section{REFERENCES}

[1]. Abraham, H. M. (1994). Motivasi dan kepribadian (Teori motivasi dengan pendekatan hierarki Kebutuhan Manusia). Jakarta: PT PBP.

[2]. Ahmadiansah, R. (2016). Pengaruh motivasi kerja dan kepuasan kerja terhadap kinerja guru Smk Muhammadiyah Salatiga. Interdisciplinary Journal of Communication, 1(2), 223-236.

[3]. Alhusaini, A., Kristiawan, M., \& Eddy, S. (2020). Pengaruh motivasi kerja dan disiplin kerja terhadap kinerja karyawan. Jurnal Pendidikan Tambusa, 4(3), 2166-2172. doi: 10.36709/jopspe.v5i1.13326.

[4]. As'ad. (2008). Psikologi industri. Yogyakarta: Liberty.

[5]. Bayu, K. (2017). Kepuasan kerja memoderasi pengaruh lingkungan kerja dan kepemimpinan kepala sekolah terhadap kinerja guru Smk Negeri 1 Pati. Proceedings, 1(1), 254-269. Retrieved online from https://ejurnal.stiedharmaputrasmg.ac.id/index.php/PRO/article/view/276.

[6]. Bono, J. E., \& Judge, T. A. (2003). Selfconcordance at work: Toward understanding the motivational effects of transformational leaders," Academic Management Journal , 46(5), 554-571.

[7]. Borman, W. C., \& Motowidlo, S. M. (1993). Expanding the criterion domain to include elements of extra-role performance. San Francisco: Jossey-Bass.

[8]. BPS. (2020). Lulusan SMK Masih Dominasi Angka Pengangguran. Retrieved online from https://www.bps.go.id.

[9]. Dou, D., Devos, G., \& Valcke, M. (2017). The relationships between school autonomy gap , principal leadership, teachers, job satisfaction and organizational commitment. Educational Management Administration Leadership, 45(6), 959-977. doi: $10.1177 / 1741143216653975$.

[10]. Ellis, C., Skidmore, S. T., \& Combs, J. P. (2017). The hiring process matters: The role of person-job and person-organization fit in teacher satisfaction. Educational Administration Quarterly, 53(3), 448-474. doi: 10.1177/0013161X16687007.
[11]. Farhah, A., Ahiri, J., \& Ilham, M. (2020). Pengaruh motivasi kerja dan disiplin kerja terhadap kinerja karyawan. Jurnal Online Program Studi Pendidikan Ekonomi, 5(1), 17. doi: 10.36709/jopspe.v5i1.13326.

[12]. Fatati, M. A., Tobing, D. S. K., \& Hana, S. W. L. (2017). Pengaruh kepuasan kerja dukungan organisasi dan motivasi kerja terhadap kinerja guru Smk swasta di Kecamatan Sumbersari. Jurnal Ekonomi, 13(2), 634, 2017.

[13]. Fu, W., \& Deshpande, S. (2014). The Impact of Caring Climate, Job Satisfaction, and Organizational Commitment on Job Performance of Employees in a China's Insurance Company. Journal Bussiness ethics, 124(2), 339-349. doi: 10.1007/s10551-013-1876-y.

[14]. Green, A. M., \& Muñoz, M. A. (2016). Predictors of new teacher satisfaction in urban schools. Journal School Leadership, 26(1) 92-123. doi: 10.1177/105268461602600104.

[15]. Guterres, L. A., \& Supartha, W. G. (2018) Pengaruh gaya kepemimpinan dan motivasi kerja terhadap kinerja dosen. Idaarah Jurnal Manajemen Pendidikan, 2(2). 155-167. doi: 10.24252/idaarah.v2i2.6533.

[16]. Guterres, L. A., \& Supartha, W. G. (2016). Pengaruh gaya kepemimpinan dan motivasi kerja terhadap kinerja guru. E-Jurnal Ekonomi dan Bisnis, 3, 429-454.

[17]. Harususilo, Y. E. (2018). Pelatihan guru SMK didukung peralatan modern. Kompas.com. Retrieved online from https://edukasi.kompas.com/read/2018/09/15/ 19321671/pelatihan-guru-smk-didukungperalatan-modern.

[18]. Hutagalung, D., Asbari, M., Fayzhall, M., Ariyanto, E., Agistiawati, E., Sudiyono, R. N., Waruwu, H., Goestjahjanti, F. S., Winanti., Yuwono, T. (2020). Peran religiusitas, kepemimpinan transformasional, kepuasan kerja dan mediasi organizational citizenship behavior terhadap kinerja guru. Journal of Education, Psychology and Counselling, 2(1), 311-326. Retrieved online from https://ummaspul.ejournal.id/Edupsycouns/article/view/483.

[19]. Kakiay, A. N. (2017). Pengaruh kepemimpinan spiritual dan kepuasan kerja terhadap kinerja guru the influence of spiritual leadership and job satisfaction on teacher 
performance. Journal Psikologi, 10(2), 148151 .

[20]. Kafumbu, F. T. (2019). Job satisfaction and teacher turnover intentions in Malawi: A quantitative assessment. International Journal Educational Reform, 28(2), 207-226. doi: 10.1177/1056787919841501.

[21]. Koedel, C., Springer, J. Li. M. G., \& Tan, L. (2017). The impact of performance ratings on job satisfaction for public school teachers. American Education Research Journal, 54(2), 241-278. doi: 10.3102/0002831216687531.

[22]. Komarudin. (2020). Menyiapkan Sdm Pendidikan sesuai dengan tantangan era revolusi industri 4.0 dan Indonesia maju. Retrieved online from http://fe.unj.ac.id/wpcontent/uploads/2020/03/03a.-Paparan-

Rektor-UNJ_Seminar-Nasional-ttg-MerdekaBelajar-di-Pasca-UNJ_10032020_Revisi.pdf.

[23]. Krivonos, P. D. (2006). The relationship of intrinsic-extrinsic motivation and communication climate in organizations. Journal of Bussiness and Communication, 15(4)-53-65.

[24]. Mangkunegara, A. A. A. (2006). Manajemen sumber daya manusia. Jakarta: Rineka Cipta.

[25]. Murdaningsih, D. (2019). Rendahnya kompetensi guru jadi masalah pendidikan Indonesia. Republika.co.id. Retrieved online from https://www.republika.co.id/berita/pq53k536 8/rendahnya-kompetensi-guru-jadi-masalahpendidikan-indonesia.

[26]. Nagar, K. (2012). Organizational commitment and job satisfaction among teachers during times of burnout. Vikalpa, 37(2), 43-60. doi: $10.1177 / 0256090920120205$.

[27]. Nasra, M. A. (2019). Leadership style and teacher performance: Mediating role of occupational perception. International Journal of Education and Management, 34(1), 186-202. doi: 10.1108/IJEM-04-2019-0146.

[28]. Noermijati. (2015). Peran kepemimpinan transformasional dan motivasi terhadap kinerja karyawan dengan moderasi masa kerja. Journal Keuangan dan Perbankan, 19(2), 326-335.

[29]. Prasetyo, B., \& Trisyanti, U. (2019). Revolusi industri 4.0 dan tantangan perubahan sosial. IPTEK Journal of Proceeding Series, $5,22-27$.

[30]. Rustamaji, C. A. P., Purwana, D., \& Yohana, C. (2017). Gaya kepemimpinan transformasional kepala sekolah dan kinerja guru SMK swasta di Jakarta Timur. Jurnal Pendidikan Ekonomi dan Bisnis, 5(2), 148161.

[31]. Shahab, M. A., \& Nisa, I. (2014). The influence of leadership and work attitudes toward job satisfaction and performance of employee," International Journal of Managerial Studies and Research, 2(5), 6977.

[32]. Siagian, S. (2007). Manajemen sumber daya manusia $\left[4^{\text {th }} e d\right)$. Jakarta: Bumi Aksara.

[33]. Sofyan, S., Prasadana, D., \& Akbar, I. R. (2020). Pengaruh motivasi , lingkungan kerja dan kepuasan kerja terhadap kinerja guru SMP/MTs Muhammadiyah Cabang Sawangan. Jurnal Ilmu Komputer dan Bisnis, 11(2), 44-55.

[34]. Suyanto, F., Rahmi, E., \& Tasman, A. (2019). Pengaruh minat kerja dan pengalaman magang terhadap kesiapan kerja mahasiswa fakultas ekonomi Universitas Negeri Padang. Ecogen, 2(5), 187-196.

[35]. Tentama, T. (2015). Peran kepuasan kerja terhadap kinerja pada guru pegawai negeri sipil (PNS) di Yogyakarta. Journal Psikologi Undip, 14(1), 1-8. doi: 10.14710/jpu.14.1.18.

[36]. Tesfaw, T. A. (2014). The relationship between transformational leadership and job satisfaction: The case of government secondary school teachers in Ethiopia. Educational Management Administration Leadership, 42(6), 903-918. doi: $10.1177 / 1741143214551948$.

[37]. Topchyan, R., \& Woehler, C. (2020). Do teacher status, gender, and years of teaching experience impact job satisfaction and work engagement? Educatiion Urban Social, 53(2), 1-21. doi: $10.1177 / 0013124520926161$.

[38]. Uly, Y. A. (2019). Pemerintah anggarkan Rp4,3 triliun untuk revitalisasi 5.000 SMK. Retrieved online from https://economy.okezone.com/read/2019/10/0 7/20/2113866/pemerintah-anggarkan-rp4-3triliun-untuk-revitalisasi-5-000-smk. 
[39]. Werang, B. R. (2014). Pengaruh kepemimpinan transformasional kepala sekolah, moral kerja guru, dan kepuasan kerja terhadap kinerja guru SDN di kota Merauke. Cakrawala Pendidikan, 1, 128-137.

[40]. Widayati, F., Fitria, H., \& Fitriani, Y. (2020). Pengaruh kepuasan kerja dan loyalitas kerja terhadap kinerja guru. Journal of Education Research, 1(3), 251-257. doi: 10.37985/jer.v1i3.29. 